\title{
Ethnobotanical Study in Martinique of the Species Behind the Local Plant Name Bwa Kaka
}

\author{
Elodie Drané $^{1 *}$, Marie Feliot-Rippeault ${ }^{1}$, Juliette Smith-Ravin ${ }^{1}$, Odile Marcelin ${ }^{1}$ \\ ${ }^{1}$ EA 929 AIHP GEODE Groupe BIOSPHERES, Université des Antilles, Martinique, F.W.I. \\ *elodie.drane@gmail.com
}

\begin{abstract}
Several scientific studies have reported that the sustainability of Traditional Knowledge (TK) is threatened by modernization. Plants of local pharmacopeias at the forefront of this phenomenon are those that are more discreet. Based on these observations, we focused on the case of a vernacular name attributed to a medicinal plant in Martinique: bwa $k a k a$. It is reported in the literature as being highly sought after by the local population but there is a lack of information about plant species behind the denomination. To identify species that correspond to bwa kaka and to record the uses associated with them, a literature review of authors in the creolophone regions from the seventeenth century to the present day was performed, followed by an ethnobotanical survey among 80 people. A use value (UV) index was calculated. It was also determined whether there was convergence of uses between these different species. Additionally, this article examines the sociocultural (age, sex, residence) factors that could influence the answers. We found that ten species were called bwa kaka. Solanum triste was the most cited species, followed by Petiveria alliacea. Among these two, $P$. alliacea had the most cultural significance based on the calculated UV. Designated uses for each species were not significantly distinct according to Fisher's Exact Test but they were significantly different depending on the sex of the interviewee. The number of uses cited was not correlated with the age of the interviewee.
\end{abstract}

Received November 1, 2017

OPEN OACCESS

Accepted March 19, 2018

DOI 10.14237/ebl.9.2.2018.1147

Keywords Folk medicine, Vernacular name, Ethnobotanical knowledge erosion, Solanum triste Jacq., Petiveria alliacea L.

Copyright (C) 2018 by the author(s) licensee Society of Ethnobiology. This is an open-access article distributed under the terms of the Creative Commons Attribution-NonCommercial 4.0 International Public License (https://creativecommons.org/licenses/by-nc/4.0), which permits non-commercial use, distribution, and reproduction in any medium, provided the original author and source are credited.

\section{Introduction}

Martinique pharmacopeia is estimated to comprise 900 products of which $92 \%$ are from plant sources, according to Nossin (Benito-Espinal et al. 2015). Among them, some have not yet been studied, but are currently in use. Our search for species of local household remedies led us to a plant called bwa kaka in Martinique. According to the literature, bwa kaka is one of the most sought-after plants in the traditional pharmacopeia in Martinique (Vilayleck 2002), a French Caribbean island. However, we had difficulty identifying the species as it was not common either on the market, where current medicinal plants can be found, or in its natural habitat. Furthermore, the literature was confusing as to the identity of bwa kaka. Indeed, the term appears for several species in the Flora of Duss as "bois caca" (1897), a word-for-word translation of bwa kaka, or "bois puant". More recently, a survey performed by Longuefosse and Nossin
(1996) in Martinique identified a single species matching this vernacular name, while Vilayleck (2002) lists two: Solanum triste (Jacq.) and Petiveria alliacea (L.). The first is an endemic species and a member of the Solanaceae family; the second is pantropical and a member of Phytolaccaceae. In order to clarify the popular knowledge linked to bwa kaka, a literature review was performed 1) to inventory all species referred to as bwa kaka in the Caribbean, 2) to identify the plant species referred to locally as bwa kaka, and 3 ) to record the traditional uses of these species and their preparation methods. Furthermore, we aim to assess the socio-cultural factors that are linked to the ethnobotanical knowledge about bwa kaka.

\section{Methods}

Survey Site

The Caribbean islands are classified as one of the 34 global biodiversity hotspots (Hobohm 2003). This study took place in Martinique, Lesser Antilles, an 
overseas French Department located between latitudes $14^{\circ} 24^{\prime} 68^{\prime \prime} \mathrm{N}$ and $14^{\circ} 51^{\prime} 53^{\prime \prime} \mathrm{N}$ and longitudes $61^{\circ} 13^{\prime} 28^{\prime \prime} \mathrm{W}$ and $60^{\circ} 49^{\prime} 05^{\prime \prime} \mathrm{W}$. Martinique is composed of a group of volcanic mountains. According to the 2008 International Union for Conservation of Nature (IUCN) Report, 26\% of Martinique is still covered by natural forest close to its primary state. Strong anthropization, regular importation of exotic species, and current environmental changes constitute a real threat to local biodiversity (Joseph 2006). Ninety-six percent (96\%) of people in Martinique live in urban areas (Clanché and Rascol 2011). Despite high urbanization and a very accessible institutional health system, people in Martinique are very attached to the local pharmacopeia and still regularly make use of medicinal plants (Concy 2015). A survey of 100 people in Martinique, performed between 1990 and 1994, identified 251 medicinal species (Longuefosse and Nossin 1996).

\section{Reference Studies}

The Creole pharmacopeia is a convergence of African, European, and Asian cultures formed at the time of plantation society, on an Amerindian substrate, originally practiced by slaves and only orally transmitted. Its knowledge has crossed the centuries in large part thanks to the written testimonies of European ecclesiastical chroniclers and botanists since the seventeenth century (Duss 1897; Du Tertre 1667; Labat 1724) and naturalist-explorers (Descourtilz 1830; Mazé 1892). It is mostly modern authors who have collected and listed popular medical practices, such as the medical practitioner Dr. Cabre (1939). More recently, agronomists, botanists, ethnobotanists, ethnologists, and anthropologists have highlighted the therapeutic interest of Caribbean flora and made an initial inventory of medicinal plants possible (Adjanohoun 1985; Benoît 1988; Bougerol 1983; Etifier-Chalono 1985; Grenand 2004; Peeters 1979; Stéhlé and Stehlé 1957; Vilayleck 2002). Encyclopedias drawn up by doctors and traditional practitioners have made this knowledge available to the general public (Beuze and Césaire 1973; Chenu 1986; Ouensanga 1983, 1993; Zamore and Ary 1984). We were able to consult these works and collect ethnobotanical data on bwa kaka at the Université des Antilles library. To obtain the names and botanical families, we used the Illustrated Flora of the Phanerograms of Guadeloupe and Martinique (Fournet 1940) and Rollet's Atlas of Trees of the Lesser Antilles (2010) for resources on local flora, and online databases for international resources (Broome et al. 2007; Missouri Botanical Garden 2016). The Smithsonian Institution's Catalogue of Seed Plants of the West Indies (Rodríguez and Strong 2012) was also an important tool for assessing the presence of species in the Caribbean.

The language of traditional medicine is Creole. Currently, inter-regional mobility plays a key role in the cultural development of these territories (Dubesset 2012). Ethnobotanical documents from several French Creole-speaking areas were consulted. A total of 28 publications were consulted, published from the seventeenth century through modern times.

\section{Ethnobotanical Survey}

The survey was performed between May and September 2014. The questionnaire used with interviewees was divided into three sections. The first section was for recording plant species that interviewees designated as bwa kaka, along with any other useful information for identifying the species. The second section asked interviewees about the traditional uses they knew, whether medicinal or otherwise, using both closed questions (in particular, frequency of use, method of preparation and administration, and the source of their knowledge) and semi-open questions (in particular, for therapeutic uses). Finally, the last section recorded the sociodemographic data on interviewees (age, sex, profession, place of residence).

Some terms used by the interviewees to describe the pains, illnesses, symptoms, treatments, and therapeutic uses, which have been reported here, are specific to Creole culture. In order to provide an overview of medicinal categories as seen in another recent study carried out in the Caribbean (TorresAlvilez et al. 2015), we classified these answers among ten categories, which correspond to the World Health Organization (WHO) International Classification of Disease (WHO 2010): 1) Diseases of the nervous system; 2) Diseases of the musculoskeletal system and connective tissue; 3) Injury; 4) Endocrine, nutritional, and metabolic diseases; 5) Certain infectious and parasitic diseases; 6) Diseases of the digestive system; 7) Diseases of the genitourinary system; 8) Diseases of the skin and subcutaneous tissue; 9) Diseases of the circulatory system; 10) Diseases of the respiratory system.

Interviewees were chosen using the "snowball sampling" method previously used and described for 


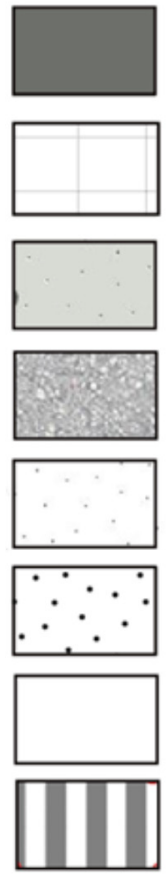

\section{zone 1}

\section{zone 2}

zone 3

zone 4

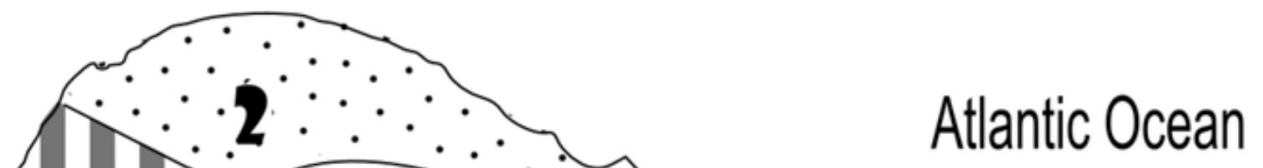

zone 5

zone 6

zone 7

\section{Caribbean Sea} zone 8

Figure 1 Map of the locality and number of interviewees in percent (\%) in each of the TRAMIL zones in Martinique.

ethnobotanical studies (Cabanting and Perez 2016; Espinosa et al. 2012; Lans 2006). This procedure consists of asking each interviewee to recommend new participants. The sample thus extends from source to source. We first used the questionnaire with prominent traditional practitioners and people who grow medicinal plants for sale in Martinique (identified via the internet, radio, local television, or recommendation by other people). Then we focused on people who regularly consume medicinal plants or occasionally use plants for treatment, who we met in markets or at events on the subjects of "plants" and "tradition". In this way, we interviewed over 80 people, men and women, from 20 to over 70 years old. We first asked if they had heard of the plant called bwa kaka. If the answer was positive, the interview continued. To obtain a sample covering the entire territory and population of Martinique, we 


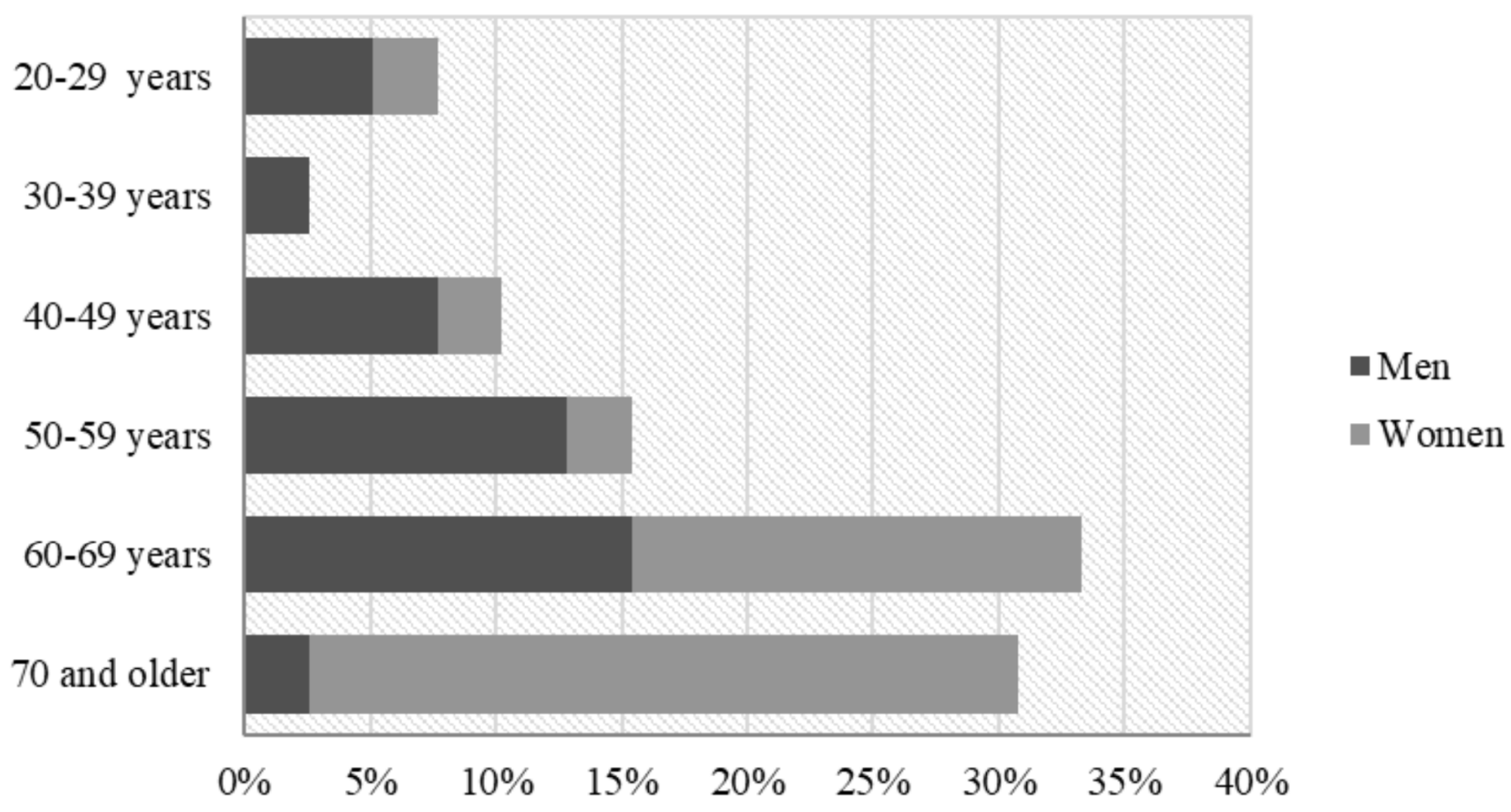

Figure 2 Distribution of interviewees according to sex and age range (among 48 respondents).

conducted the survey across the eight zones specified in the TRAMIL method (Longuefosse and Nossin 1996). These zones were determined by criteria such as microclimate, vegetation, population, level of urbanization, type of economy and persistence of tradition (Figure 1). 10.2\% of people interviewed were from Zone 1, 14.3\% from Zone 2, 14.3\% from Zone 3, $16.3 \%$ from Zone 4, 22.4\% from Zone 5, 2.0\% from Zone 6, $10.2 \%$ from Zone 7, and $10.2 \%$ from Zone 8.

For the first section of the questionnaire, plant samples were collected (where possible and with the interviewee's permission) and identified by A. Clodius, a botanist at the Martinique Regional Nature Park, and by comparison to the flora described by Fournet (1940); the specimens were then taken to be dried and preserved in the laboratory collection and at the herbarium of the French National Institute for Agricultural Research (INRA), Guadeloupe (INRA 2018). Each sample collected during the survey is linked with a form describing the plant and a photograph. However, some interviews were performed off-site, in which case it was not possible to observe or gather a sample of the living plant in its environment. In these instances, the strategy used to identify the species involved recording descriptions that were as detailed as possible (size, color, form, and structure of the flower, leaves, and entire plant, and any similarities to another species) and using images of selected species as had been practiced in earlier studies (Ruysschaert et al. 2009). These images were photo sheets, supplemented by a drawing and the scientific name for eight plants that the literature specified as being known as bwa kaka in the Caribbean.

\section{Analysis of Survey Data}

The completed questionnaires were first entered into Sphinx Plus ${ }^{2}$ V5 (Le Sphinx Développement), then into a secondary database created in Microsoft Excel 2007, containing nominal data such as the botanical species, uses, and interviewee profiles (place of residence, occupation). The data collected was coded and analyzed using the same software. Citation frequencies were calculated using the equation: $\mathrm{F}=\mathrm{Ni} / \mathrm{Np} \times 100$, where $\mathrm{Ni}$ is the number of informants using this species for a specific illness and $\mathrm{Np}$ is the total number of informants using the plants medicinally (Boulogne et al. 2011).

The use value index was calculated as follows: $\mathrm{UV}=\mathrm{U} / \mathrm{N}$, where $\mathrm{U}$ is the number of uses mentioned 
by all informants for a given species, and $\mathrm{N}$ the total number of informants. This is an index used to assess the significance of a plant taxon, based on its relative use within a population (Phillips and Gentry 1993). To analyze the results obtained for identification of species and the uses attributed to them, we postulated that: 1) there is a link between interviewee zone of residence and plant species designated, 2) the uses cited for bwa kaka differ depending on the species designated. This result is an indicator of similarity of uses and their possible convergence for the different species. Furthermore, two other null hypotheses were tested, related to interviewee profiles: 3 ) the use cited depends on the sex of the interviewee, and 4) the number of uses cited correlates with the age of the survey participant. To assess the first three hypotheses, contingency tables were constructed and Fisher's Exact Test applied (a test for uniformity of variances). Finally, for the fourth hypothesis, a Kendall's tau correlation test was applied. The tests were performed using the $\mathrm{R}$ software environment, version 3.2.1.

\section{Results and Discussion}

\section{Profile of Interviewves}

Of the 82 people interviewed, $48(58.5 \%)$ had heard of the plant called bwa kaka and replied to the full questionnaire, and $12(14.6 \%)$ had used it personally. The sample of respondents who had heard of the plant (48 people) was made up of $56.3 \%$ men and $43.8 \%$ women distributed across various age groups (Figure 2). The sampling led us to interview seven traditional practitioners and eight sellers of medicinal plants and derived products. The 33 other people interviewed were consumers of traditional medicine.

We also observed that the interviewees had most often acquired knowledge of the uses from their parents (intergenerational transmission: 27 of the 48 interviewees that knew bwa kaka, or 56.3\%). Other sources were their circle of friends (6 of the 48 interviewees that knew bwa kaka, or $12.5 \%$ ), and research on the internet, in books, or in the paramedical or medical environment (5 of the 48 interviewees that knew bwa kaka, or 10.4\%). Thus, the majority of the interviewees acquired their knowledge from their parents. This reflects the authenticity and fragile nature of most of the data collected concerning bwa kaka. Indeed, the elders historically transmit creole pharmacopeia orally.
Identification of Species from Analysis of Bibliographical and Survey Data

In the literature, ten scientific plant names were found to be associated with the vernacular term bwa kaka. Nine species are indigenous to the Caribbean islands and two are endemic in the Lesser Antilles. One species is indigenous to India: Sterculia foetida L. There is a species of the same genus, which is endemic to the Lesser Antilles: Sterculia caribaeae L. (Table 1). Solanum triste is the species with the largest number of citations in the literature. Petiveria alliacea is only cited once.

Bwa kaka was identified by 45 interviewees during the survey. Ten interviewees provided samples (voucher numbers from UI GUAD 14215 to 14225 , see Notes). Thirty-five others provided a description of the different plant organs, fruits, and flowers which was used to identify the species or identified the plant from the photo sheets provided. Three more interviewees were unable to identify the species, but knew about the traditional uses of the plant called bwa kaka. Three interviewees cited several species. In total, six different species were identified as bwa kaka: $S$. triste (34 times, or $75.6 \%$ ), P. alliacea (13 times, or $28.9 \%$ ) and $S$. foetida (2 times, or $4.4 \%$ ) were the most cited (Figure 3). Ocotea cernua, Siparuna glabrescens, and Piper dilatatum were cited once (not shown on the figure). Of the 15 traditional medical practitioners interviewed, $10(66.7 \%)$ cited S. triste, $4(26.7 \%)$ cited P. alliacea, and $1(6.7 \%)$ cited Piper dilatatum. It should therefore be noted that identification of the species corresponding to bwa kaka by the population followed the same trend as that of traditional practitioners.

Among the ten species of bwa kaka reported in the local literature (Table 1), five were confirmed by the survey: S. triste, P. alliacea, S. foetida, Ocotea cernua, and Siparuna glabrescens. S. triste, which is cited the most frequently in the literature, is also the most cited during the survey. However, P. alliacea, which is cited the most by interviewees after $S$. triste, is referenced once in the literature. Capparisflexuosa, which is the most cited in the literature after $S$. triste, was not cited during the field study. The difference between the literature results and the actual current knowledge of medicinal plants is an evidence of a shift in this knowledge. Another interesting result is that $P$. alliacea, the second most cited by interviewees during the survey, appears to have been reported just once in the literature. P. alliacea is therefore thought to be a recent inclusion. 
Table 1 Species found under the vernacular name bwa kaka in the local literature.

\begin{tabular}{|c|c|c|c|}
\hline Species & Family & Origin & $\begin{array}{l}\text { Bibliographic } \\
\text { references for } \\
\text { bwa kaka }\end{array}$ \\
\hline Ocotea cernua (Nees) & Lauraceae & $\begin{array}{l}\text { Indigenous to the Caribbean } \\
\text { (Acevedo-Rodríguez \& } \\
\text { Strong, 2012) }\end{array}$ & $\begin{array}{l}\text { Graveson 2009; } \\
\text { Rollet } 2010\end{array}$ \\
\hline Bunchosia glandulosa (Cav.) & Malpighiaceae & $\begin{array}{l}\text { Indigenous to the Caribbean } \\
\text { (Acevedo-Rodríguez \& } \\
\text { Strong, 2012) }\end{array}$ & $\begin{array}{l}\text { Grandtner 2005; } \\
\text { Rodríguez and } \\
\text { Strong 2012; } \\
\text { Timyan } 1996\end{array}$ \\
\hline Solanum triste (L.) & Solanaceae & $\begin{array}{l}\text { Indigenous to the Lesser } \\
\text { Antilles and South America }\end{array}$ & $\begin{array}{l}\text { Beuze and Césaire 1973; } \\
\text { Duss 1897; Fournet 1940; } \\
\text { Longuefosse and Nossin } \\
\text { 1996; Mazé 1892; Rollet } \\
\text { 2010; Sastre et al. 2007; } \\
\text { Vilayleck } 2002\end{array}$ \\
\hline Petiveria alliacea (L.) & Phytolaccaceae & $\begin{array}{l}\text { Indigenous to the Caribbean } \\
\text { and Central America } \\
\text { (Acevedo-Rodríguez \& } \\
\text { Strong, 2012) }\end{array}$ & Vilayleck 2002 \\
\hline $\begin{array}{l}\text { Guettarda parviflora (Vahl), } \\
\text { syn. } \\
\text { G. odorata (Jacq.) Lam. }\end{array}$ & Rubiaceae & $\begin{array}{l}\text { Indigenous to the Caribbean } \\
\text { and Central and South } \\
\text { America }\end{array}$ & $\begin{array}{l}\text { Mazé 1892; } \\
\text { Rollet 2010; } \\
\text { Sastre et al. 2007; } \\
\text { Duss } 1897\end{array}$ \\
\hline $\begin{array}{l}\text { Siparuna glabrescens } \\
\text { (C. Presl), syn. } \\
\text { S. santae-luciae }\end{array}$ & Siparunaceae & $\begin{array}{l}\text { Endemic to the Lesser } \\
\text { Antilles }\end{array}$ & Rollet 2010 \\
\hline $\begin{array}{l}\text { Capparis flexuosa (L.) syn. } \\
\text { C. cynophallophora (L.) }\end{array}$ & Capparaceae & Indigenous to the Caribbean & $\begin{array}{l}\text { Grandtner 2005; } \\
\text { Mazé 1892; } \\
\text { Rodríguez and } \\
\text { Strong 2012; } \\
\text { Timyan } 1996\end{array}$ \\
\hline Capparis ferruginea (L.) & Capparaceae & $\begin{array}{l}\text { Indigenous to the Greater } \\
\text { Antilles }\end{array}$ & $\begin{array}{l}\text { Beauvoir 2006; } \\
\text { Mazé 1892; } \\
\text { Descourtilz } 1833\end{array}$ \\
\hline Sterculia caribaea (R. Br.) & Sterculiaceae & $\begin{array}{l}\text { Endemic to the Lesser } \\
\text { Antilles }\end{array}$ & $\begin{array}{l}\text { Broome et al. 2007; } \\
\text { Mazé 1892; } \\
\text { Rodríguez and } \\
\text { Strong } 2012\end{array}$ \\
\hline Sterculia foetida (L.) & Sterculiaceae & Exotic, indigenous to India & $\begin{array}{l}\text { Mazé 1892; } \\
\text { Priam et al. 2015; } \\
\text { Rollet } 2010\end{array}$ \\
\hline
\end{tabular}




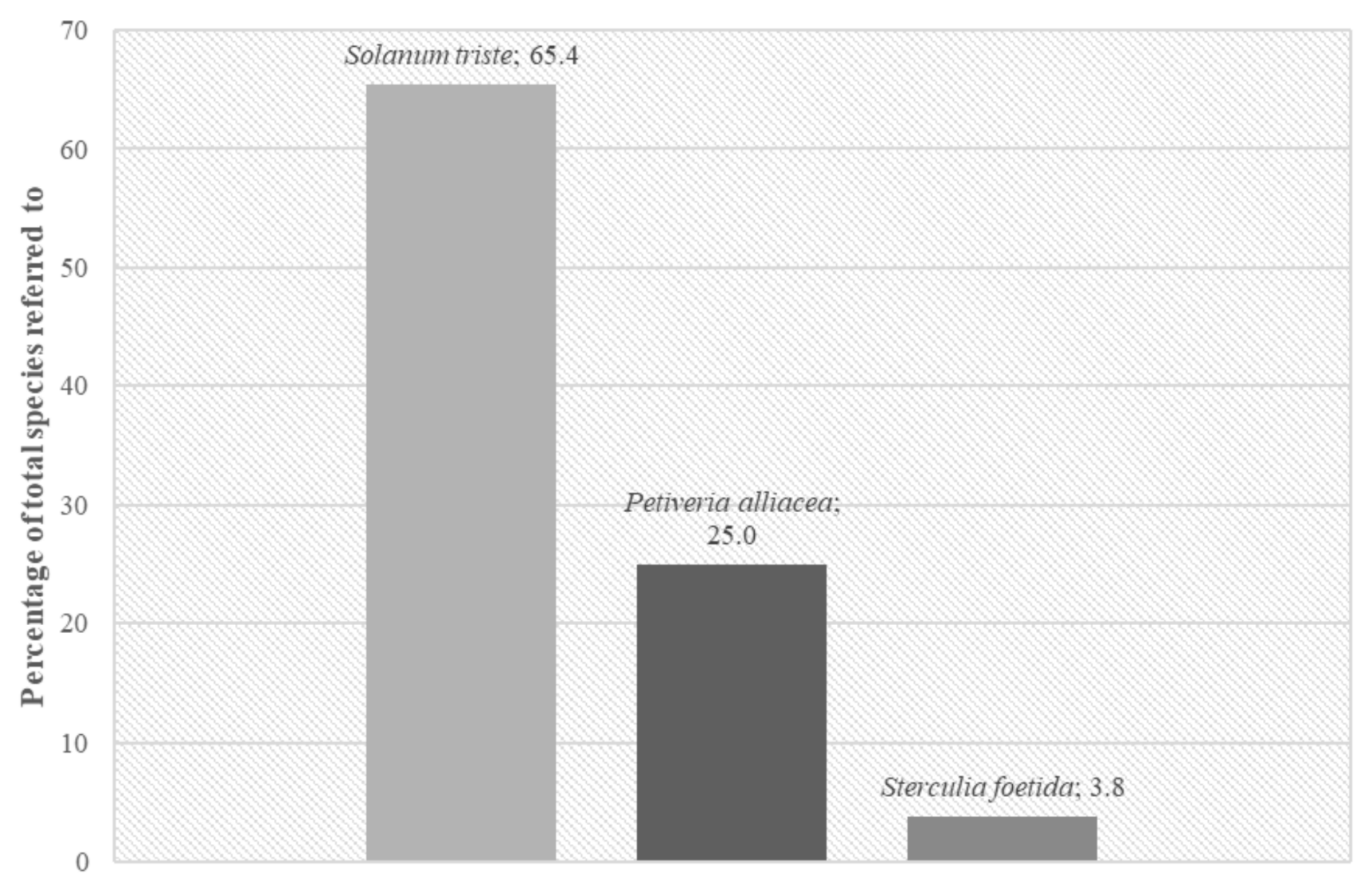

Figure 3 Main species designated as bwa kaka during the survey: S. triste, P. alliacea and S. foetida (among 52 answers).

Bwa kaka is an example of what Rollet (2010) calls an "englobant" (encompassing) vernacular name attributed to several botanical species. This can be a source of confusion when the person who gives therapeutic advice is not the same person who supplies the herbal remedy, and also in cases where people practice self-medication. In Martinique, it is customary to distinguish between the traditional practitioner who diagnoses and prescribes, and the herbalist, who supplies the treatment as well as knowing and harvesting the plants and their methods of preparation. The herbalists, who are historically usually women (Nossin 2006), are also called lapotijè (Creole for "apothecary") and they are found in the main markets. Those encountered in the survey cultivated their herbs in their own gardens (in Creole: jaden bo kay) or they gathered plants in the relatively wild grounds around their dwellings (in Creole: zèb razie . Alongside this type of market sale, there are an increasing number of commercial nurseries that produce medicinal plants.
From the survey, two species, S. triste and $P$. alliacea, were frequently cited (34 and 13 times, respectively). The first species is a shrub that can reach $7 \mathrm{~m}$ in height and that grows in relatively humid areas. During the survey, the areas cited for gathering S. triste were along forest edges, not far from human activities, and only two interviewees cultivated it. The second species is an herbaceous plant that is sometimes suffrutescent. It appears to be easy to distinguish on the basis of these morphological features. However, a clarification of the lexicogenic matrices that define the vernacular denomination of plant species offers elements of explanation. Indeed, in Caribbean Creole culture, a plant is usually named on the basis of features such as its morphological, organoleptic, functional, circumstantial, or ecological characteristics, from which names are generated (Villayleck 1993). In the case of bwa kaka, the base term bwa means "wood" (from the French bois) and it is usually reserved for trees. S. triste is a shrub and $P$. alliacea an herbaceous plant. Consequently, S. triste 
Table 2 Correspondence between World Health Organization (WHO) categories and therapeutic uses cited by survey participants.

\begin{tabular}{|c|c|}
\hline WHO categories & Uses uncovered during the survey \\
\hline Certain infectious and parasitic diseases & Elephantiasis \\
\hline Diseases of the digestive system & $\begin{array}{l}\text { Digestive problems (colic, veisaglia, aerophagia), Intestinal } \\
\text { inflammations (hemorrhoids) }\end{array}$ \\
\hline Diseases of the genitourinary system & Kidney stones \\
\hline Diseases of the skin and subcutaneous tissue & Skin conditions \\
\hline Diseases of the circulatory system & “Heavy legs" \\
\hline Diseases of the respiratory system & Flu, Sinusitis \\
\hline Diseases of the nervous system & Headaches \\
\hline $\begin{array}{l}\text { Diseases of the musculoskeletal system and connective } \\
\text { tissue }\end{array}$ & Rheumatism, Inflammatory joint pain \\
\hline Injury and certain other consequences of external causes & $\begin{array}{l}\text { Sprains, Hematomas, Blesse (chest pain caused by a } \\
\text { brusque movement) }\end{array}$ \\
\hline Endocrine, nutritional, and metabolic diseases & Diabetes, Cholesterol \\
\hline
\end{tabular}

would be a better candidate for this name than $P$. alliacea according to these criteria. The second part of the name, kaka, means "feces" and is open to several interpretations, of which the most common, based on replies obtained during the survey, evokes the nauseating odor of the plant. On this criterion, both species could be a good match. Indeed, the phytochemical study of $P$. alliacea has shown that it contains sulfur compounds that are structurally similar to those that give garlic its characteristic odor (Luz et al. 2016). Some species of the Solanum genus are said to have an unpleasant odor (Gentry 1993), though the odor has not been linked to specific volatile compounds in the genus (Visser et al. 1979). From these observations, it is entirely plausible that people attribute the same name to the two species. However, given that one is favored over the other, the hypothesis can be posited that $S$. triste was the first to be called bwa kaka, and that P. alliacea was later called by the same name because of its quality as a "bad smelling plant".

We wanted to determine if the names used for a particular species were linked to the location. Indeed, Vilayleck (1993) indicated that vernacular names given to species in Martinique are associated with the location where they are given. This is not confirmed by our results since our test shows that there is no significant difference between the zones where $S$. triste and $P$. alliacea were named $(p$-value $=0.3226)$. In other words, the species designated as bwa kaka are therefore not significantly correlated with the geographical zones of the survey. This result could point out a trend towards an increase in uniformity in knowledge and practices associated with the mobility of people on the island. Indeed, Martinique is a small territory which has modernized rapidly, as shown by the development of roads and means of transport since the 1960s (Guignard 1985).

Uses of Bwa Kaka

Of the 48 people who answered the questionnaire (including the three people that could not identify the species), $66.7 \%$ (32 people) were able to cite uses for bwa kaka and $25 \%$ (12) of them used it personally. Among the 37 suggestions of uses, three categories were cited: therapeutic $(75.7 \%$ of responses), home hygiene (10.8\%), and magic-religious purposes $(13.5 \%)$ such as chasing away dorlis (a supernatural malicious character in popular Martinique belief), keeping away people with bad intentions, ben démaré purification rites, success in exams, or general protection.

The medicinal uses were catalogued and linked to the WHO International Classification of Diseases (Table 2). They include vernacular terms such as gueule de bois (hangover) and more academic terms such as kidney stones, diabetes, cholesterol, and aerophagia, alongside words and expressions from a form of local 


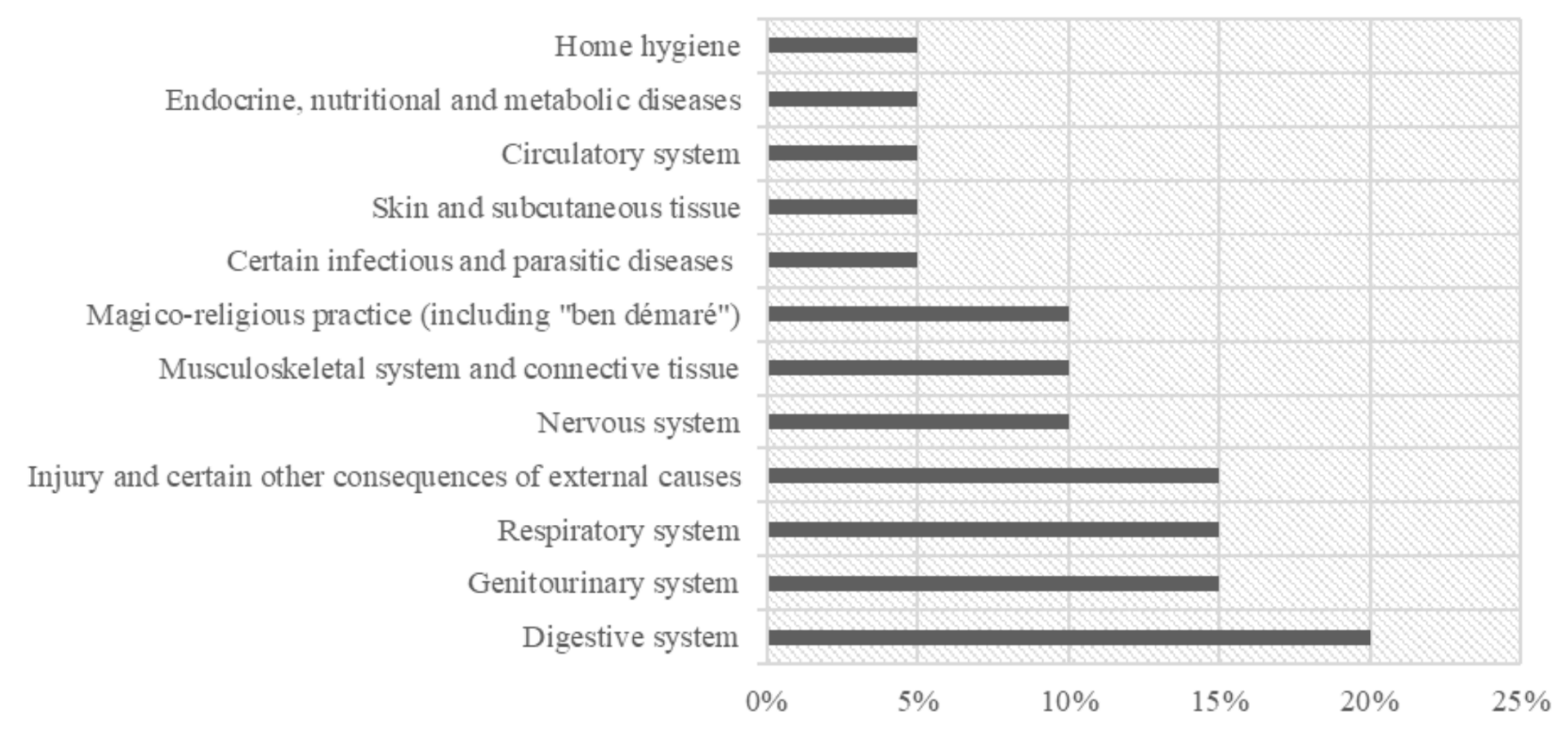

Figure 4 Popular uses of S. triste according to citation frequencies (among 20 respondents).

nosology (blesse, ben démaré, lenflamasyon). The latter term is the Creole version of the word "inflammation". In French as in English, inflammation is a type of immune system response. In Creole, it refers to a series of symptoms associated with an excess of "heat" and is treated with refreshing herbal teas which re-establish lost equilibrium (Longuefosse and Nossin 1996).

For the remaining analysis of the results, we focused on the two species most cited in our survey, $S$. triste and P. alliacea. The illnesses that received the most citations for $S$. triste were diseases of the digestive system, followed by those of the genitourinary system, the respiratory system, and injuries (Figure 4). P. alliacea tends to be most frequently used in the treatment of metabolic and endocrine diseases (Figure 5). However, these variations between the uses attributed to each of the two species are not statistically significant, according to Fisher's Exact Test ( $p$-value=0.5189). With regard to bwa kaka preparation methods, over $99 \%$ of users use the leaves of both species. The main bwa kaka preparation methods were aqueous maceration (6 of the 14 answers, or $42.9 \%$ ), decoction ( 2 of the 14 answers, or $14.3 \%$ ), fumigation (1 of the 14 answers, or $7.1 \%$ ), and no preparation or processing (5 of the 14 answers, or $35.7 \%$ ). The methods of administration stated were oral (8 of the 14 answers, or $57.14 \%$ ), as a poultice (5 of the 14 answers, or $35.7 \%$ ), or in a bath (1 of the 14 answers, or $7.1 \%$ ). This led us to consider the risk of convergence of uses for these two species. We have little information on the phytochemical composition and toxicity of $S$. triste, but we know that this species belongs to a family that contains glycoalkaloids that are potentially toxic for humans (Ginzberg et al. 2008; Maxwell et al. 1995, 1996). P. alliacea is a medicinal species indigenous to tropical America that is widely distributed in tropical areas of America, Caribbean, and Africa, where it is used for its medicinal properties. Its extracts are associated with antitumor activities (Hernández et al. 2014) and the essential oils have demonstrated antimicrobial properties (Kerdudo et al. 2015). Mutagenic and potentially carcinogenic effects of the extracts have been demonstrated but more tests are needed to conclude on the toxicity of folk medicine based on P. alliacea (Luz et al. 2016).

As some authors have noted, traditional medicine, which was for a long time essential to local people in the Caribbean, has been marginalized to make way for modern medicine (Mitchell and Ahmad 2006; Vaudreuil 2012). Some studies suggest that elders have better knowledge on medicinal plants (Hodge and Taylor 1957; Longuefosse and Nossin 1996). However, our experience in the field suggests otherwise for this area. Indeed, the total number of 


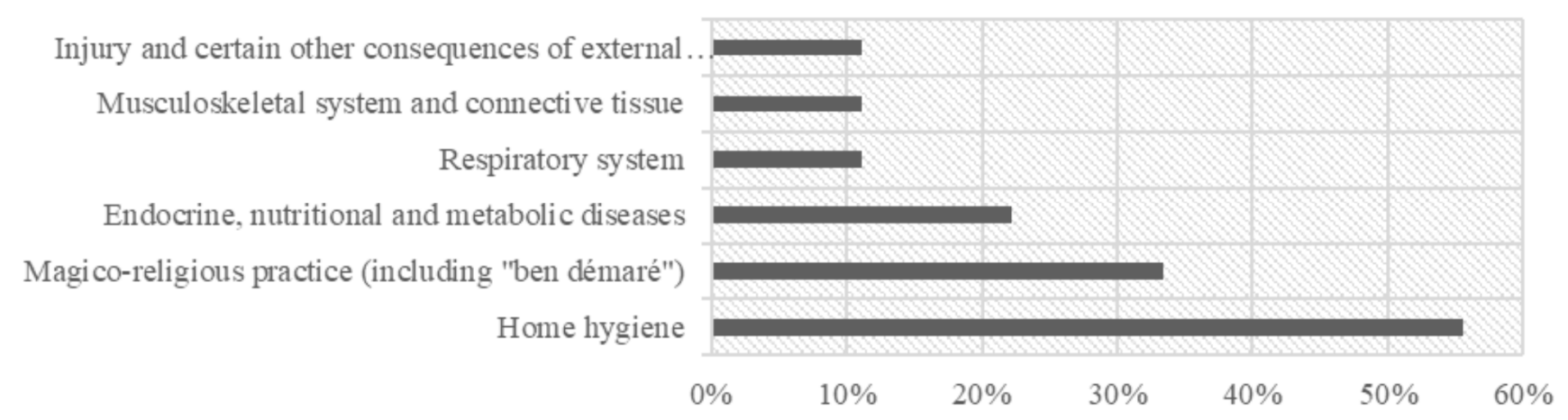

Figure 5 Popular uses of $P$. alliacea according to citation frequencies (among 9 respondents).

uses described by participants in the age ranges 50 $59,60-69$, and 70-79 years old were under two, while we had more than two uses from interviewees aged under 39. The Kendall's tau test did not indicate a significant correlation coefficient between the number of uses cited and the age of the interviewee $(\tau=0.09$, $p$-value $=0.4905)$. The number of uses cited by men and women were not significantly different $(p$ value $=0.5887)$. The literature indicated that, from the original inhabitants of Martinique, the Amerindians, to the modern inhabitants, women were the heirs and protectors of traditional knowledge on medicinal plants (Longuefosse 2006; Quinlan and Quinlan 2007). Our results cannot confirm this theory. Regarding the category of uses cited by the interviewee, the results of Fisher's Exact Test differ significantly $(p$-value $=0.0464)$. Indeed, men stated that bwa kaka was mainly used for the treatment of diseases of the digestive system while for women the main use was magic-religious practice. Thus, from these results, we concluded that the category of uses is linked to the sex of the interviewee. Our results reflect the fact that a change involving custodians of ethnobotanical knowledge may be underway in Martinique. To this effect, a few studies have already been carried out in the Caribbean (Torres-Avilez et al. 2015; Quinlan and Quinlan 2007).

For $S$. triste, the calculated use value was $\mathrm{UV}=0.60$ and for P. alliacea UV=0.67. This reflects the greater cultural significance of the second species. This confirms earlier conclusions that $S$. triste has a declining place in local popular practices and lore. While bwa kaka seems to have been quite sought after in the past (Vilayleck 2002), its use seems to have now regressed. Indeed, the plant was only available on request at the four largest markets in Martinique (one in Trinité, and three in Fort de France). There are several possible explanations. It may be the victim of its reputation as a plant used for "sorcery", since one of the main uses recorded during our survey on the vernacular name bwa kaka was its magic-religious use. According to local belief, it is not good to disclose the use of such plants as they risk losing their effectiveness (Nossin 2006). An additional explanation is that modern society in Martinique, like in other places in the world (Lee et al. 2001), has less place for these practices and consequently the species associated with these practices are neglected and they become rarer. This has been the case in the past for the Caribbean species Maranta ruizana (Körn), according to the ethnobotanist J. Barrau (1995).

\section{Conclusion}

The study illustrates the potential side effects of the erosion of traditional knowledge, leading to interspecific use convergence and potential problems for public health, as has been underlined in other studies (Olivier et al. 2015; Yamani et al. 2015). The survey sheds light on S. triste, a species indigenous to the Lesser Antilles which has been the subject of few published scientific studies. S. triste is one of those plants that for various reasons has been marginalized over the course of history and is currently underexploited. According to our survey, it is designated in Martinique under the same vernacular name as $P$. alliacea, the second most frequently cited species for bwa kaka, and four other species. P. alliacea is available and used in many countries, but its local traditional uses in Martinique are perhaps undergoing major transformations since it was not listed as bwa kaka in the literature before Vilayleck (2002). We hypothesize that it is a recent inclusion in the pharmacopeia. Furthermore, the results show that the uses are not 
significantly distinct for the two most frequently cited species. It would therefore be of interest to check the safety of $S$. triste for therapeutic ends, particularly when ingested as an infusion. Our laboratory will later study its phytochemistry.

Ethnobotanical studies can allow the development of biodiversity conservation strategies (Albuquerque et al. 2009) by identifying the more fragile species, threatened with the disappearance of wild areas by human activity. We think that $S$. triste is a good candidate for these strategies. Indeed, the species is very rare in its natural habitat (Delnatte 2015). We also noted during our survey that few people cultivated S. triste. They generally picked it in secondary mesophilic forest areas, not far from dwellings and human activities. Consequently, this species is more sensitive than $P$. alliacea to the degradation of its environment. More investigations on the field are needed to evaluate its ecology in Martinique.

A look at the sociocultural background of the interviewees suggests elements of the dynamics of acquisition, transmission, and loss of traditional knowledge. In our investigations, we also found that general theories of traditional knowledge of pharmacopeia in the literature do not always correspond to observations in the field. Indeed, the age and gender of the custodians of knowledge in this study were not what was previously reported in the literature on Martinique. To confirm this trend, a broader study is needed with a larger population and a larger number of species.

\section{Notes}

Voucher specimens were deposited in the Herbarium of INRA, Centre Antilles-Guyane, Guadeloupe. The datasets used and analyzed during the current study are available from the corresponding author.

\section{Acknowledgements}

The authors thank Dr. Christian de Vassoigne and Dr. Emmanuel Nossin for providing support on the design of the survey. A special thanks to the traditional practitioners, the market vendors, and the people in Martinique who volunteered to share their knowledge about medicinal plants. We thank Alex Clodius from the Parc Naturel Régional de Martinique (PNRM) who was a great support in the field for the localization and identification of plant species.

\section{Declarations}

Permissions: Ethics approval was not required for our case reports. All data were collected under previous consent of each participant.

Source of funding: The project was supported by the Région Martinique and Collectivité Territoriale de Martinique (CTM).

Conflicts of Interest: None declared.

\section{References Cited}

Adjanohoun, E., 1985. Contribution aux Études Ethnobotaniques et Floristiques à la Dominique (Commonwealth of Dominica): Rapport Présenté à l'A.C.C.T. Agence de Coopération Culturelle et Technique, Paris.

Albuquerque, U.P. de, T.A. de Sousa Araújo, M.A. Ramos, V.T. do Nascimento, R.F.P. de Lucena, J.M. Monteiro, N.L. Alencar, and E. de L. Araújo. 2009. How Ethnobotany Can Aid Biodiversity Conservation: Reflections on Investigations in the Semi-Arid Region of NE Brazil. Biodiversity and Conservation 18:127-150. DOI:10.1007/s10531-0089463-8.

Barrau, J. 1995. Deux Espèces de Maranta Alimentaires Cultivées aux Petites Antilles. Journal d'Agriculture Traditionnelle et de Botanique Appliquée 37:133-138. DOI:10.3406/jatba.1995.3565.

Beauvoir, M.-G. 2006. The Caribbean Herbalist [web page]. URL: http://vodou.org/caribherbalist.htm. Accessed on February 15, 2016.

Benito-Espinal, F.P. and J. Dumont. 2015. L'Usage des Plantes Médicinales aux Antilles et en Guyane. Karthala, Paris, France. Available at: https://hal.univantilles.fr/hal-01540169. Accessed on February 15, 2016.

Benoît, C. 1988. Une Parole en Situation. Du Dit au Non-Dit dans une Enquête Ethnobotanique à la Guadeloupe. Bulletin de l'Association Française des Anthropologues. 31:65-74. DOI:10.3406/ jda.1988.1376

Beuze, R. and J.-P. Césaire. 1973. La Santépar les Plantes: des Antilles Françaises. Émile Desormeaux, Fort-de-France, Martinique.

Bougerol, C. 1983. La Médecine Populaire à la Guadeloupe. Paris: Karthala.

Boulogne, I., L. Germosén-Robineau, H. OzierLafontaine, M. Fleury, and G. Loranger-Merciris. 2011. TRAMIL Ethnopharmalogical Survey in Les 
Saintes (Guadeloupe, French West Indies): A Comparative Study. Joumal of Ethnopharmacology 133:1039-1050. DOI:10.1016/j.jep.2010.11.034.

Broome, R., K. Sabir, and Carrington S. 2007. Plants of the Eastern Caribbean, EC Flora Online [web page]. URL: http://ecflora.cavehill.uwi.edu/ index.html. Accessed on May 12, 2014.

Cabre, H. 1939. Flore de la Guadeloupe et Dépendances: Notes de Phytothérapie Allopathique et Homéopathique Comparées 3. Imprimerie Catholique, Basse-Terre, Guadeloupe.

Cabanting, R.M.F., and L.M. Perez. 2016. An Ethnobotanical Study of Traditional Rice Landraces (Oryza sativa L.) Used for Medical Treatment in Selected Local Communities of the Philippines. Journal of Ethnopharmacology 194:767-73. DOI:10.1016/j.jep.2016.10.021.

Chenu, J. 1986. Plantes Médicinales des Antilles. Vol. 1-6. Dajani, Pointe-à-Pitre, Guadeloupe.

Clanché, F. and O. Rascol. 2011. Le Découpage en Unités Urbaines de 2010. L'Espace Urbain Augmente de 19\% en une Décennie. INSEE Première No. 1364. Available at: https:/ / www.insee.fr/fr/statistiques/1280970. Accessed on July 8, 2017.

Concy, H. 2015. La Transmission du Patrimoine Médicinal Créole: Problématique, Pertinence, et Évaluation d'un Savoir Traditionnel. Doctoral Dissertation, Université Antilles-Guyane, France. Available at: http:// www.theses.fr/2015AGUY0865. Accessed on February 29, 2016.

Delnatte, C. 2015. French Neotropical Solanum Genus. In Advances in Environmental Research 42:5371, edited by J.A. Daniels. Nova Science Publishers, Hauppauge, NY.

Descourtilz, M.E. 1830. Flore Pittoresque et Médicale Des Antilles ou Histoire Naturelle des plantes Usuelles des Colonies Françaises, Anglaises, Espagnoles, et Portugaises. Paris. Available at: http:// www.biodiversitylibrary.org/item/23234\#page/21/ mode/1up. Accessed on February 29, 2016.

Du Tertre, J.-B. 1667. Histoire Générale des Antilles Habitées par les François. Vol. 2 \& 3. T. Jolly Paris, France. Available at http://gallica.bnf.fr/ ark:/12148/bpt6k1140206. Accessed on February 29, 2016.
Dubesset, E. 2012. Penser Autrement l'Identité Régionale Caribéenne. Études Caribéennes 21. DOI:10.4000/etudescaribeennes.5739.

Duss, A. 1897. Flore Phanérogamique des Antilles Françaises: Martinique et Guadeloupe. Protat frères, Mâcon, France.

Espinosa, M.M., I.G.C. Bieski, and D.T.O. Martins. 2014. Sampling in Ethnobotanical Studies of Medicinal Plants. In Methods and Techniques in Ethnobiology and Ethnoecology, pp. 197-212. Springer Protocols Handbooks. Humana Press, New York, NY.

Etifier-Chalono, M.-E., 1985. Etude Descriptive des Jardins Traditionnels des Campagnes de Sainte-Marie, Martinique. Doctoral Dissertation, Université Montpellier. Atelier Duplication U.S.T.L., Montpellier, France.

Fournet, J. 1940. Flore Illustrée des Phanérogames de Guadeloupe et de Martinique. CIRAD \& Gondwana Editions, Trinité, Martinique.

French National Institute for Agricultural Research (INRA) Guadeloupe. 2018. Centre de Ressources Biologiques: Plantes Tropicales [web page]. URL: http:/ / collections.antilles.inra.fr/A. Accessed on June 30, 2018.

Gentry, Alwyn H. 1993. A Field Guide to the Families and Genera of Woody Plants of Northwest South America (Colombia, Ecuador, Peru), with Supplementary Notes on Herbaceous Taxa, pp. 53, 787. Conservation International, University of Chicago Press, Chicago.

Ginzberg, I., J.G. Tokuhisa, and R.E. Veilleux. 2008. Potato Steroidal Glycoalkaloids: Biosynthesis and Genetic Manipulation. Potato Research 52:1-15. DOI:10.1007/s11540-008-9103-4.

Grandtner, M.M. 2005. Elsevier's Dictionary of Trees: Volume 1: North America. pp. 123, 151. Elsevier, Amsterdam, The Netherlands.

Graveson, R. 2009. Plant Taxonomy of Saint Lucia. National Forest Demarcation and Bio-Physical Resource Inventory Project Caribbean-Saint Lucia. Technical Report 4 European Commission and Banana Industry Trust. Finnish Consultancy Group (FCG) International Ltd in association with AFC Consultants International GmbH. Available at: http://www.saintlucianplants.com/ downloads.html/. Accessed on May 15, 2014.

Grenand, P. 2004. Pharmacopées Traditionnelles en Guyane: Créoles, Wayãpi, Palikur. ORSTOM, Paris, France. 
Hobohm, C. 2003. Characterization and Ranking of Biodiversity Hotspots: Centres of Species Richness and Endemism. Biodiversity and Conservation 122:279287. DOI:10.1023/A:1021934910722.

Hodge, W.H., and D. Taylor. 1957. The Ethnobotany of the Island Caribs of Dominica. Webbia 12:513644. DOI:10.1080/00837792.1957.10669669.

Joseph, P. 2006. L'Invasion Annoncée des Espèces Végétales Introduites dans les Petites Antilles: L'Exemple de la Martinique, Paris. Revue d'Ecologie la Terre et la Vie 61:209-224. Available at: http:// hdl.handle.net/2042/55681. Accessed on June 10, 2014.

Kerdudo, A., V. Gonnot, E. Njoh Ellong, L. Boyer, T. Michel, S. Adenet, K. Rochefort, and X. Fernandez. 2015. Essential Oil Composition and Biological Activities of Petiveria alliacea L. from Martinique. Journal of Essential Oil Research 27:186-96. DOI:10.1080/10412905.2015.1014118.

Lans, C. 2006. Ethnomedicines Used in Trinidad and Tobago for Urinary Problem and Diabetes Mellitus. Journal of Ethnobiology and Ethnomedicine 13:45-51. DOI:10.1186/1746-4269-2-45.

Longuefosse, J.-L. and E. Nossin. 1996. Medical Ethnobotany Survey in Martinique. Journal of Ethnopharmacology 53:117-142. DOI:10.1016/03788741(96)01425-0.

Longuefosse, J.-L. 2006. Le Guide de Phytothérapie Créole: Bien se Soigner par les Plantes Créoles. Orphie, Chevagny-sur-Guye, France.

Luz, D.A., A.M. Pinheiro, M.L. Silva, M.C. Monteiro, R.D. Prediger, C.S. Ferraz Maia, and E.A. FontesJúnior. 2016. Ethnobotany, Phytochemistry, and Neuropharmacological Effects of Petiveria alliacea L. (Phytolaccaceae): A Review. Journal of Ethnopharmacology 185:182-201. DOI:10.1016/ j.jep.2016.02.053.

Mazé, H. 1892. Contribution à la Flore de la Guadeloupe. Imprimerie du Gouvernement, Basse-Terre, Guadeloupe. Available at: http://

www.biodiversitylibrary.org/bibliography/2746. Accessed on June 16, 2014.

Maxwell, A., M. Seepersaud, R. Pingal, R.M. David, and F.R. William. 1995. 3 $\beta$-Aminospirosolane Steroidal Alkaloids from Solanum Triste. Journal of Natural Products 58:625-28. DOI:10.1021/ np50118a027.
Maxwell, A., M. Seepersaud, R. Pingal, R.M. David,

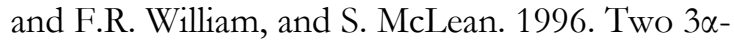
Aminospirosolane Steroidal Alkaloids from Solanum triste. Journal of Natural Products 59:200-201. DOI:10.1021/np960059c.

Mitchell, S.A., and M.H. Ahmad. 2006. A Review of Medicinal Plant Research at the University of the West Indies, Jamaica, 1948-2001. West Indian Medical Journal 55:243-269.

Nossin, E. 2006. Enquête Ethnopharmacologique sur le Grand Marché de Fort-de-France.

Ethnopharmacologia 38:23-29.

Olivier, D.K., S.F. Van Vuuren, and A.N. Moteetee. 2015. Annickia affinis and A. chlorantha (Enantia chlorantha) -A Review of Two Closely Related Medicinal Plants from Tropical Africa. Journal of Ethnopharmacology 176:438-62. DOI:10.1016/ j.jep.2015.10.021.

Ouensanga, C., 1983. Dictionnaire Plantes et Remèdes. Plantes Médicinales et Remèdes Créoles. Vol. 2. Désormeaux, Fort-de-France, Martinique.

Paniagua-Zambrana, N., R. Cámara-Leret, R.W. Bussmann, and M.J. Macía. 2016. Understanding Transmission of Traditional Knowledge across North-Western South America: A Cross-Cultural Study in Palms (Arecaceae). Botanical Journal of the Linnean Society 182:480-504. DOI:10.1111/ boj.12418.

Peeters, A. 1979. La Pocaution cé Manman Félicité. Communications 31:130-144. DOI:10.3406/ comm.1979.1474.

Phillips, O. and A.H. Gentry. 1993. The Useful Plants of Tambopata, Peru: I. Statistical Hypotheses Tests with a New Quantitative Technique. Economic Botany 47:15-32. DOI:10.1007/BF02862203.

Priam, F., O. Marcelin, E. Nossin, and J. Smith-Ravin. 2015. Sterculia foetida L., le Sterculier Fétide, une Espèce à Potentiel de l'Ethnopharmacopée de Martinique. Ethnopharmacologia 53.

Quinlan, M.B. and R.J. Quinlan. 2007. Modernization and Medicinal Plant Knowledge in a Caribbean Horticultural Village. Medical Anthropology Quarterly 21:169-192. DOI:10.1525/maq.2007.21.2.169.

Rodríguez, P.A. and M.T. Strong. 2012. Catalogue of Seed Plants of the West Indies. Smithsonian Contributions to Botany 98:1-1192. DOI:10.5479/ si.0081024X.98.1. 
Rollet, B. 2010. Arbres des Petites Antilles. Tome 2. Description Des Espèces. ONF, Paris, France.

Ruysschaert, S., T. R. van Andel, K. Van de Putte, and P. Van Damme. 2009. Bathe the Baby to Make it Strong and Healthy: Plant Use and Child Care Among Saramaccan Maroons in Suriname. Journal of Ethnopharmacology 121:148-170. DOI:10.1016/ j.jep.2008.10.020.

Sastre, C., A. Breuil, J.-F. Bernard, P. Feldmann, and J. Fournet. 2007. Plantes, Milieux, et Paysages des Antilles Françaises: Écologie, Biologie, Identification, Protection, et Usages. Biotope, Mèze, France.

Stéhlé, H. and M. Stehlé. 1957. Flore Médicinale Illustrée des Antilles Françaises. Vol. 9. Flore Agronomique des Antilles Françaises. Imprimerie Lautric, Pointe-àPitre, Guadeloupe. Available at: http:/ / uag.cyberlibris.com/reader/local/docid/88805251/ page/2. Accessed on May 15, 2014.

Sujarwo, W., I.B.K. Arinasa, F. Salomone, G. Caneva, and S. Fattorini. 2014. Cultural Erosion of Balinese Indigenous Knowledge of Food and Nutraceutical Plants. Economic Botany 68:426-437. DOI:10.1007/ s12231-014-9288-1.

Timyan, J. 1996. Bwa Yo, Important Trees of Haiti. South-East Consortium for International Development. Washington D.C., 20006: Library of Congress Catalog. Available at: http:/ / www.cabdirect.org/abstracts/19980606961.html. Accessed on May 25, 2015.

Torres-Avilez, W., M. Méndez-González, R. DuránGarcía, I. Boulogne, and L. Germosén-Robineau. 2015. Medicinal Plant Knowledge in Caribbean Basin: A Comparative Study of Afrocaribbean, Amerindian, and Mestizo Communities. Journal of Ethnobiology and Ethnomedicine 11:18. DOI:10.1186/ s13002-015-0008-4.

Vaudreuil, C. 2012. A Propos de Deux Registres Nécessaires au Bon Usage des Plantes Médicinales de
Martinique: La Pharmacopée Végétale Martiniquaise et un Vadémécum de Phytothérapie. Doctoral Dissertation, Université de Rouen, UFR de Médecine et de Pharmacie, France. Available at: https:/ / dumas.ccsd.cnrs.fr/dumas-00707349 Accessed on October 17, 2016.

WHO. 2010. International Statistical Classification of Diseases and Related Health Problems: 10th Revision (ICD-10). Available at: http:// www.who.int/classifications/icd/en/. Accessed on March 17, 2017.

Vilayleck, E. 1993. Les Noms de Plantes en Créole Martiniquais: À la Recherche de Modèles. Doctoral Dissertation, Université Antilles-Guyane, France. Available from Campus de Schoelcher Library, Martinique, France.

Vilayleck, E. 2002. Ethnobotanique et Médecine Traditionnelle Créoles: Contribution à l'Etude du Lexique de l'Habitation. Presses Universitaires Créoles GEREC/F. Ibis Rouge, Paris, France.

Visser, J.H., S. van Straten, and H. Maarse. 1979. Isolation and Identification of Volatiles in the Foliage of Potato, Solanum tuberosum, a Host Plant of the Colorado Beetle, Leptinotarsa deficemlineata. Journal of Chemical Ecology 5:13-25. DOI:10.1007/ BF00987684.

Yamani, A., V. Bunel, M.-H. Antoine, C. Husson, C. Stévigny, P. Duez, M. Elachouri, and J. Nortier. 2015. Substitution between Aristolochia and Bryonia Genus in North-Eastern Morocco: Toxicological Implications. Journal of Ethnopharmacology 166:250260. DOI:10.1016/j.jep.2015.03.036.

Zamore, R. and E. Ary. 1984. Vertus et Secrets des Plantes Médicinales des Antilles. Edouard Kolodziej, Paris, France. 